\title{
Economics of Buffalo in Livestock Production System in Punjab: Current Status and Future Prospectus
}

\author{
Varinder Pal Singh* and Inderpreet Kaur
}

Department of Dairy Economics and Business Management, College of Dairy Science and Technology, Guru Angad Dev Veterinary and Animal Sciences University, Ludhiana-140111, Punjab, India

*Corresponding author

\section{A B S T R A C T}

\begin{tabular}{|l|}
\hline K e y w o r d s \\
$\begin{array}{l}\text { Male calf, Milk yield, } \\
\text { Production traits, Profit, } \\
\text { Size category, Variable } \\
\text { cost }\end{array}$ \\
\hline Article Info \\
\hline $\begin{array}{l}\text { Accepted: } \\
\text { 20 September } 2018 \\
\text { Available Online: } \\
10 \text { October } 2018\end{array}$ \\
\hline
\end{tabular}

\section{Introduction}

Livestock sector contributes about 26 per cent of the total GDP from agricultural sector in India (Govt of India, 2017a). Livestock sector plays an important role in Punjab agriculture as evidenced from its contribution to the total agricultural GDP which is recorded at 36 per cent during 2016-17 and continuously improving over the time (Govt of Punjab, 2017). During the last five years period, the growth rate of livestock sector is observed to be 5.05 per cent as compared to only 0.46 per cent in crop sector. The Punjab state is producing 11.28 million tonne (6.9 per cent) milk of India with only 2.53 per cent dairy

\begin{abstract}
Buffaloes contribute a chunk to the total milk production in the Punjab state and have many advantages over cow milk and hence it is also known as black gold. The present study has been conducted in seven districts across three agro-climatic zones of the Punjab state to study the comparative economics of buffaloes and cow. It has been observed from In the case of buffaloes, the overall profit excluding the family labour expenditure observed to be Rs 4.62/litre which was highest for large category i.e. Rs 7.32 /litre followed by medium and small category. The profit in domestic category was negative. Hence, the minimum size of the buffalo dairy farming should be at least 7 milch animals. Besides milk, male buffalo calves can be reared as separate enterprise for earning additional income and generating employment.
\end{abstract}

animals and stands first in terms of per capita milk availability (1075 gm/day vs $352 \mathrm{gm} /$ day) in the country (Govt of India, 2017a). Punjab is leading milk producing state in the country with highest milk production per animal both in cross bred cattle (12.72 litres/day) and buffaloes (8.21 litres/day). India has 108.7 million buffaloes and 190.90 million cattle (Govt of India, 2014). The cross breeding has helped the country a lot in enhancing the milk production and becoming number one milk producer in the world. In India, the number of cross bred cattle has increased from 20.10 million during 1997 to 39.73 million during 2012 which is 20 per cent of the total cattle population in the country. The process of cross 
breeding in cattle was very fast in Punjab state which is known for its role in green revolution, where it has reached as high as 85 per cent. Despite of this, buffalo still contributes a chunk to the total milk production in the state. Considering these facts and figures, the case of Punjab state is being studies for economic aspects of buffalo farming. Punjab state has 24.28 lakh cows out of which 85 per cent are cross bred cows. On the other hand, there are 51.60 lakh buffaloes and buffalo being the native animal, is well adapted to the local climatic conditions and resistant to various diseases and parasites. Contribution of buffalo milk to the total milk production of the state is more than $71 \%$ as compared to $49.1 \%$ at national level (201617). Cross bred cattle, indigenous cattle and goats contribute about 26 per cent, 2 per cent and 1 per cent milk respectively. The milk group contributes about 81 per cent of the value of output from livestock sector and out of that 81 per cent, a major part (about 80 per cent) is contributed by buffalo milk and only 20 per cent is contributed by cow milk (Govt. of India 2017b). With this background and importance of buffalo in milk livestock production system of Punjab state, the present paper aims to present the comparative economics of buffalo and cow, various issues and concerns in buffalo farming and suggest policy measures for development of buffaloes, hence enhancing their profitability.

\section{Materials and Methods}

The economics of cross bred cattle and buffaloes has been studied across three zones of the Punjab state in six selected districts over a period of seven years with the financial support of Punjab Dairy Development Board during the period 2009 to 2014. The study covered about 600 dairy farmers (100 from each selected district) and each farmer was interviewed at monthly intervals so as record the change in various components of cost of milk production in various seasons. The dairy farms were divided into four size categories for the detailed study i.e. domestic (1-2 animals), small (3-7 animals), medium (8-15 animals) and large (>15 animals). The other required secondary data has been taken from various published sources.

\section{Results and Discussion}

\section{Economics of crossbred cattle and buffaloes in livestock production system of Punjab}

The economics of buffaloes and cross bred cattle has been discussed in this section.

\section{Milk yield}

It has been observed from the study that the yield of buffaloes has almost stagnated at 7.74 litres/day while that of cross bred cattle has improved slightly from 10.21 to 10.48 litres/day (Fig. 1).

\section{Production traits from field survey}

Production traits are important from economic point of view as these affect the overall profitability from dairy farming. There is need of research on improving the production traits so as to make buffalo farming more profitable. Age at first calving is important production trait affecting profitability from dairy farm as a whole. For the buffaloes, age at first calving was observed to be 3.8 years and milk production during lactation period was recorded at 2158 litres (Table 1). Inter calving period was observed to be 471 days out of which 284 were wet days and 187 dry days. For the cross bred cattle, age at first calving was observed to be 2.5 years and milk production during lactation period was recorded at 3269 litres. Inter calving period was observed to be 372 days out of which 303 were wet days and 69 dry days. We need to work on reducing the age at first calving 
particularly in the case of buffaloes so that the cost of rearing a buffalo heifer can be lowered. Similarly there is need to reduce the inter calving period and enhancing the lactation yield.

\section{Economics of milk production}

Profitability of dairy farming depends upon the milk yield, price of milk and cost of milk production. Therefore, it is essential to know the cost of milk production in rural areas so that efforts can be made to cut down the unit cost of production and hence increasing the profitability.

The overall profit from cattle excluding the family labour expenditure was observed to be Rs 3.88/litre which was highest for large category i.e. Rs 6.10 /litre followed by medium and small category (Table 2). The profit in domestic category was only Rs $0.47 /$ litre.

In the case of buffaloes, the overall profit excluding the family labour expenditure was observed to be Rs 4.62/litre which was highest for large category i.e. Rs 7.32 /litre followed by medium and small category. The profit in domestic category was negative. Hence, the minimum size of the dairy farming should be at least 7 milch animals. The veterinary expenses were higher for cross bred cattle (2.84 per cent of variable cost) compared to buffaloes (1.12 per cent of variable cost) (Table 3).

\section{Issues and concerns}

Buffalo farming is facing various issues and concerns which affect the profitability directly and indirectly. These issues need to be addressed adequately and timely for ensuring the sustainable development of buffalo farming. Some of such issues and concerns are discussed below.

\section{Breeding objectives: liquid milk vs constituents}

There is need of relooking at breeding objectives and add components of calving difficulties, longevity and mastitis. Why should we waste more energy to produce water and sugar through milk.

Milk contains $12-15 \%$ solids and rest is water.56 times more energy is needed to produce a $\mathrm{kg}$ of fat and 28 times more for a $\mathrm{kg}$ of protein. Buffalo milk is rich in fat (7\%), protein $(4.5 \%)$, and minerals than Cross Bred milk (fat-4\%, protein-3.2\%). CB yielding $4000 \mathrm{~kg}$ milk with $4 \%$ fat (160 kg fat, $56 \mathrm{~kg}$ protein)- near equivalent to buffalo yielding $2300 \mathrm{~kg}$ milk with $7 \%$ fat (161 kg fat, $106 \mathrm{~kg}$ protein); Has A2 allele-No health issues. An adult bovine with $450-500 \mathrm{~kg}$ would be ideal from perspective of sustainability and should be considered.

\section{Stray cattle}

The cross bred cattle are not well adapted to local conditions and require a lot of attention and cost of maintenance. Moreover, there is problem of disposal of unproductive animals and male calves as the cow slaughtering is not allowed on religious grounds. Another important challenge is the problem of stray cattle. Currently the number of stray cattle is One lac (Table 4) and with new dairy policy there number would increase to 14.21lac animals which means additional burden of Rs $1556 \mathrm{cr}$ per year.

The stray animals are causing economic and social damage to the society e.g. destroying the field crops, road accidents, traffic jams etc. Burden on the government for maintenance of stray cattle will be about Rs 5800 crore per annum in India. There is no such problem of stray animals in buffaloes as slaughtering is allowed. 
Table.1 Production traits from field survey

\begin{tabular}{|l|l|l|}
\hline Type of Animal & Production Traits & 3.8 \\
\hline Buffalo & Age at Ist Calving (years) & 284 \\
\hline & No. of Days in Milk & 187 \\
\cline { 2 - 3 } & Dry Days & 471 \\
\cline { 2 - 3 } & Inter-calving period (Days) & 2158 \\
\hline & Milk production during lactation period (in litres) & 2.5 \\
\hline \multirow{2}{*}{ Cross bred Cow } & Age at Ist Calving (years) & 303 \\
\cline { 2 - 3 } & No. of Days in Milk & 69 \\
\cline { 2 - 3 } & Dry Days & 372 \\
\hline & Inter-calving period (Days) & 3269 \\
\hline
\end{tabular}

Source: Inderpreet Kaur and Varinder Pal Singh

Table.2 Economics of milk production in Punjab

\begin{tabular}{|c|c|c|c|c|c|}
\hline Particulars & Domestic & Small & Medium & Large & Overall \\
\hline \multicolumn{6}{|l|}{ CATTLE } \\
\hline Milk yield (Litre) & 7.20 & 9.00 & 11.94 & 15.36 & 10.48 \\
\hline Cost of milk production, Rs/litre/day/farm & 25.60 & 23.80 & 21.60 & 19.91 & 22.32 \\
\hline Dairy Enterprise Profit, (Rs/litre) & -3.12 & -1.48 & 2.92 & 4.92 & 1.02 \\
\hline $\begin{array}{l}\text { Dairy Enterprise Profit, (Rs/litre) (Excluding } \\
\text { labour) }\end{array}$ & 0.47 & 1.12 & 4.10 & 6.10 & 3.88 \\
\hline \multicolumn{6}{|l|}{ BUFFALO } \\
\hline Milk yield (Litre) & 5.95 & 7.73 & 8.62 & 9.66 & 7.71 \\
\hline Cost of milk production, Rs/litre/day/farm & 35.01 & 33.22 & 29.91 & 27.91 & 29.72 \\
\hline Dairy Enterprise Profit, (Rs/litre) & -4.37 & -2.12 & 3.98 & 5.99 & 2.65 \\
\hline $\begin{array}{l}\text { Dairy Enterprise Profit, (Rs/litre) (Excluding } \\
\text { labour) }\end{array}$ & -0.02 & 1.32 & 5.52 & 7.32 & 4.62 \\
\hline
\end{tabular}

Source: Inderpreet Kaur and Varinder Pal Singh

Table.3 Veterinary Expenses of Buffalo and Cow (Rs. Per day per farm) over the years based on field survey in Punjab

\begin{tabular}{|l|c|c|c|c|}
\hline YEAR & $\begin{array}{c}\text { Veterinary Expenses } \\
\text { (Rs.) BUFFALO }\end{array}$ & $\begin{array}{c}\text { \% of Variable } \\
\text { Cost }\end{array}$ & $\begin{array}{c}\text { Veterinary Expenses } \\
\text { (Rs.) COW }\end{array}$ & $\begin{array}{c}\text { \% of Variable } \\
\text { Cost }\end{array}$ \\
\hline $\mathbf{2 0 1 0}$ & 10.50 & 1.42 & 16.83 & 1.77 \\
\hline $\mathbf{2 0 1 1}$ & 14.56 & 1.32 & 21.53 & 1.54 \\
\hline $\mathbf{2 0 1 2}$ & 13.83 & 1.32 & 34.11 & 2.32 \\
\hline $\mathbf{2 0 1 3}$ & 13.29 & 1.17 & 45.67 & 3.10 \\
\hline $\mathbf{2 0 1 4}$ & 14.37 & 1.12 & 54.11 & 2.80 \\
\hline
\end{tabular}

Source: Inderpreet Kaur and Varinder Pal Singh 
Table.4 Stray cattle in Punjab and India

\begin{tabular}{|l|c|c|c|}
\hline Particulars & Rural & Urban & Total \\
\hline India & 43.06 & 9.82 & 52.88 \\
\hline Punjab & 0.82 & 0.19 & 1.01 \\
\hline
\end{tabular}

Source: $19^{\text {th }}$ livestock census

Table.5 Rise in milk production if these uncalved animals are made calved at least one time

\begin{tabular}{|l|c|}
\hline Category & Milk production (Est.) \\
\hline Crossbred cattle & $0.147 \mathrm{MT}$ \\
\hline Indigenous cattle & $0.016 \mathrm{MT}$ \\
\hline Buffaloes & $0.245 \mathrm{MT}$ \\
\hline Total & $0.41 \mathrm{MT}$
\end{tabular}

Source: $19^{\text {th }}$ livestock census (Calculations made by the authors)

Table.6 Livestock vs crop subsidies in Punjab

\begin{tabular}{|l|c|c|c|c|}
\hline Sector & $\begin{array}{l}\text { GDP (TE16-17) } \\
\text { Crore) }\end{array}$ & $\begin{array}{l}\text { Subsidies (TE 17-18 } \\
\text { (Rs Crore) }\end{array}$ & $\begin{array}{l}\text { Subsidies as \% of } \\
\text { GDP }\end{array}$ & $\begin{array}{l}\text { Subsidy } \\
\text { /acre }\end{array}$ \\
\hline Crop & 61057.26 & 8602.153 & 14.089 & 9445.85 \\
\hline Livestock & 32062.85 & 4.966 & 0.015 & 41.27 \\
\hline Fisheries & 1213.85 & 5.032 & 0.415 & 1240.47 \\
\hline
\end{tabular}

Govt. of Punjab (Calculations made by the authors)

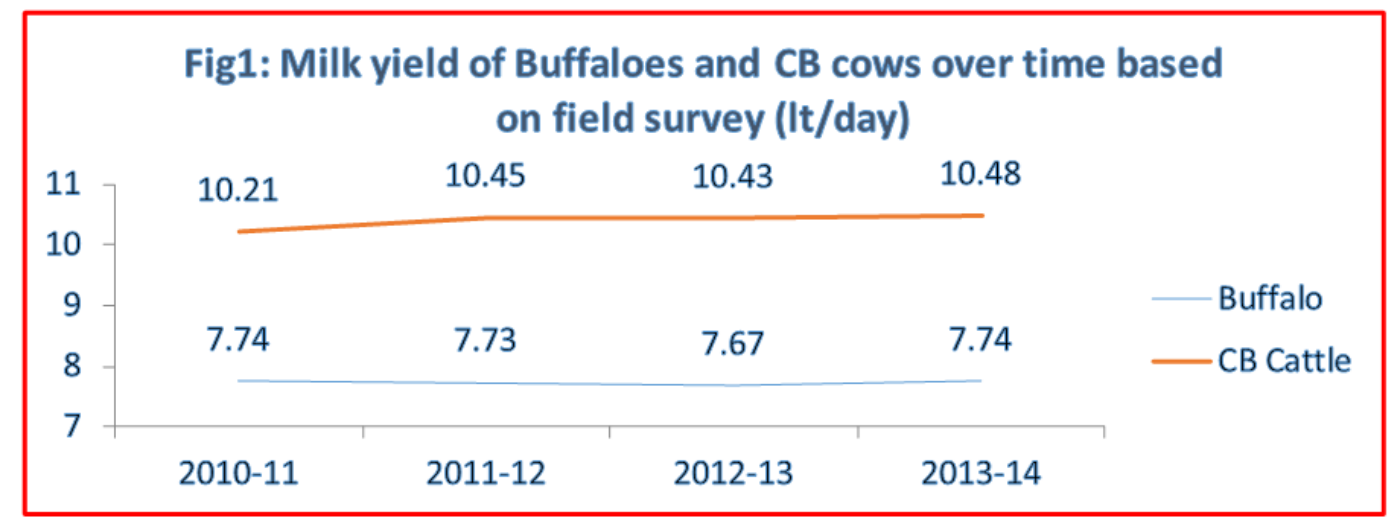

\section{Problems of buffalo farmers}

Problem of heat detection is the main problem faced by buffalo farmers which result in economic losses. During the study, about 91 per cent dairy farmers reported the problem of repeat breeding among the animals, 76 per cent farmers reported the incidence of reproductive disorders and 51 per cent farmers reported the problem of heat detection. Local veterinary hospitals and dispensaries lack tools to diagnose critical problems of milch animals and young one calves. It means the state needs more multi- 
facility fully equipped hospitals with expert and trained staff to counter such problems. There is acute shortage of manpower to manage these institutions and provide required services.

\section{Policy suggestions}

Based on the analysis of the study, the suggestions and policy implications for sustainable buffalo farming development in Punjab are discussed below:

\section{Prioritization of objectives}

Among livestock, buffaloes and crossbred cows form priority and account for more than $90 \%$ of value of output. Bovine numbers are now stabilized with male to female ratio being 10:90; Buffaloes are and shall continue to be more economical because of value at the end of productive life. Milk yield/day in Buffaloes and $\mathrm{CB}$ is 8.21 and $12.72 \mathrm{~kg}$, the highest in country. Priority to increase yield levels to $11 \mathrm{~kg}(3000 \mathrm{~kg} / \mathrm{lactation})$ in buffaloes and $15 \mathrm{~kg}$ (5000kg/lactation) in HF crossbreds should be there. Yield levels below $6.8 \mathrm{~kg}$ in buffaloes and $8.5 \mathrm{~kg}$ in $\mathrm{CB}$ are not economically sustainable.

\section{Breedable population}

Breedable population in Punjab28.04 lakh for buffaloes, 11.81 lakh CB cattle and 1.14 lakh indigenous cattle.

The proportion of not even calved once animals is 3.50 per cent, 3.22 per cent and 7.02 per cent in the case of buffaloes, $\mathrm{CB}$ cattle and indigenous cattle respectively. If these uncalved animals are calved at least one time, additional 0.41million tonnes (Table 5) means can be produced which means that total milk production in the state would be 11.69 million tonnes and the per capita milk availability would be $1114 \mathrm{~g}$.

\section{Importance of buffalo meat}

Further, the potential of buffaloes can be realized through the sale of unproductive animals for meat which is accepted socially and religiously unlike cow meat. There is no such issue of disposal of unproductive animals and male calves in the case of buffaloes and hence no issue of stray buffaloes. Buffalo meat contribution to total meat production is $50 \%$ in Punjab and 19.61 $\%$ in India.

Buffalo meat is a potential source of income for the dairy farmers. 1323.57 thousand tonnes $(91.22 \%)$ of buffalo meat worth Rs 26,162 crore was exported during 2016-17. Punjab produces $8.58 \%$ of India's buffalo meat with only $4.75 \%$ buffalo population.

The male buffalo calves can be reared as an independent allied enterprise which is economical and can help in generating additional income and employment in the state. Buffalo meat is the healthiest meat because of lower intramuscular fat, cholesterol and calories, higher in essential amino acids etc. There is need of putting more emphasis on buffalo improvement for enhanced milk production on one side and realizing its potential through sale of calves and unproductive animals for meat.

\section{Comparative advantage of buffalo milk in value addition}

The milk of buffalo is rich in fat and SNF, therefore, more suitable and economical for value added products (Mozzarella, Khoa, sweets etc.). The buffalo milk adds higher value through processing of milk into various milk products as compared to cow milk. Buffalo milk have better sensory properties: flavour and colour. It is having nutritional benefits i.e. high calorific value, higher vitamins and minerals, lower cholesterol. 


\section{Livestock vs crop subsidies in Punjab}

In Punjab state, power subsidy is $54.33 \%$ and fertilizer subsidy $45.05 \%$ of total crop subsidy, rest is subsidy on wheat seed, agri machinery, horticulture etc. The \% share of livestock subsidies is quite low compared to crop subsidies. The crop sector account for 14 per cent of GDP whereas livestock subsidies are only 0.015 per cent of the GDP. Of the livestock subsidies, the dairy subsidies constitute $91.62 \%$ \& goat and pig subsidies are only $8.38 \%$ (Table 6).

\section{Acknowledgements}

The authors are thankful and acknowledge the financial support provided by Punjab Dairy Development Board, Chandigarh. The authors are grateful to $\mathrm{Dr}$ A.S. Nanda, Vice Chancellor, Guru Angad Dev Veterinary and Animal Sciences University, Ludhiana for providing necessary infrastructural facilities for carrying out the research.

Buffaloes contribute a chunk to the total milk production in the state. Buffalo milk have many advantages compared to cow milk. The buffalo milk adds higher value through processing of milk into various milk products as compared to cow milk. Moreover, there is no problem of disposal of unproductive animals and male calves as slaughtering is allowed. Male buffalo calves can be reared as separate enterprise for earning additional income and generating employment. The various problems being faced by the buffalo rearing farmers need to be addresses properly for promoting this species. The livestock sector should receive the due attention for adequate investments and subsidies in this sector at par with the crop sector.

\section{References}

Govt. of India. 2014. $19^{\text {th }}$ livestock census 2012 All India Report, Ministry of Agriculture, Department of Animal Husbandry, Dairying and Fisheries, Government of India, New Delhi.

Govt. of India. 2017a. Basic Animal Husbandry Statistics. Department of Animal Husbandry, Dairying and Fisheries, Ministry of Agriculture, Government of India, New Delhi.

Govt. of India. 2017b. State wise and item wise estimates of value of output from agriculture and allied sectors, Central Statistics Office, Ministry of Statistics and Programme implementation, Govt. of India.

Govt. of Punjab. 2017. Statistical Abstract of Punjab. Economic Advisor to Government, Economic and Statistical Organization, Chandigarh.

Kaur, I., and Singh, V.P. 2014. Report of Project "Economics of milk production and its regular monitoring in Punjab" submitted to Punjab Dairy Development Board, Chandigarh.

\section{How to cite this article:}

Varinder Pal Singh and Inderpreet Kaur. 2018. Economics of Buffalo in Livestock Production System in Punjab: Current Status and Future Prospectus. Int.J.Curr.Microbiol.App.Sci. 7(10): 2702-2708. doi: https://doi.org/10.20546/ijcmas.2018.710.314 